\section{Community Development as a strategy to Rural Development}

\author{
Kailash Pyakuryal'
}

Community Development can be viewed as an approach to rural development. Community development focuses more on interacting human beings withln a geographical boundary whereas, rural development embraces more an ecological perspective.

Human settlements are found both in rural, as well as, urban areas, but rural development programs are designed to affect rural people. Commonly addressed issues are rural pove rty, illiteracy, ill health, regional disparity, unequal power or the other. Rural development aims to improve the standard of living of rural people. Thus community development can be viewed as a straregy to rural development. This paper is organized into 3 sections. First section deals with the concept of commun!ty development, second section deats with the rise and fall of community development and the last section ends with the concluding remarks.

1 Professor of Rural Sociology, Central Department of Sociology and Anthropology, Tribhuvan University, Kirtipur, Kathmandu.
1. Community Development

After the rigorous analysis of all the available 44 definitions of community, George A. Hillery Jr. in his article "Definitions of Community: Areas of Agreement" has attempted to generalise the following :

i. That there is no complete agreement among sociologists as to the nature of community,

i i. That certain ecologists have been the most radical deviant in formulating the concept of community,

i i i. That with the ecological relations viewpoint excluded, others agree on the social institutions,

iv. That in defining rural community they agreed mostly that rural community has an area in which social interation and one or more common bonds were found (Hillery pp. 111123).

The term community has very loosely been used else where such as a "communily of sportsmen", "Buddhist community". "International community", or "world community". Such usage do not communicate the sociological meaning of the term for discussion and analysis so for the purpose of conceptual clarity, the following essential components could be considered to the meaning of a rural community in Nepal:

i. There must be a group of interacting people on the basis of mutual dependence and concern,

i i. Who live in a well defined and limited geographical area,

i i i. Who have a sense of belonging or identification or community consciousness,

iv. They have common social values, norms, and other aspects of culture, and

v. The cornmunity should have some necessary social instimtions i. e., schools, governing agency, credit agency etc. 
Community development can be viewed as 'Self-Help, Approach to Rural Development. Under the 'self-help' philosophy of development there is an attempt made to enlist and inspire the people in the determination of desirable change in goals and in the implementation of program to bring about the change deemed desirable.

Other agency,s role (outside the traget system) are expected to maintain neutrality in decision-making episodes yet they play organizational and informational roles. This approach is appealing because of its apparent compatibility with democratic ideology.

The distinctive feature of community development is the participation by the people themselves in efforts to improve their levels of living with reliance as much as possible on their own initiative; and the provision of technical and other services in ways which encourage initiative, self-help and mutual help and make them more effective. The principal advantage cited by champions of the self-help type of program (C. D.) is the involvement of the people themeslves in the decision and program implementation processes. Such involvement secures participation and greminates the feeling of being involved in ones destiny. Another advantage, frequenily cited, is that local persons are Knowledgeous about their problems and people and this lessens the risk of objectives being jeopardized because of the ignorance of local beliefs and customs which characterize outside agents.

The disadvantages of this approach can also be listed in two droad headings: First is what may be called as the in-experience and inertia of localities. Local people seldom have the sophistication to comprehend problems in an over-all sense that is think in the abstract about society-wide benefits.

There is also a difficulty in keeping them interested over a period of time. A lack of progress quickly dissipates their enthusiasm as volunteers any may even lead to more negative reactions. The second broad disadvantage of the selfhelp approach is the complex nature of societal structures. Very few problems can be solved with only local resources, communities seek and need governmental and non-governmental assistance in varying degrees in obtaining essential expert advice, economic resources, and technological items. This involvement tends to negate idea of self-help to a certain extent. In summary then, the problems which tend to plague the planners of C. D. programs are a function of the long and risky volunteer process and of the outsicio help needed to get such programs under way and to bring them to a successful conclusion. These disadvantages are recognised by the practitioners of C. D. programs but are generally excused as a necessary encumbrance of democratic process.

\section{Hise and Fall of Community Development}

Soon after the second world war, colonial empires crumbled and foreign rulers departed, leaving the unfinished task of rural development for their successors. The old problems remained unsolved, complicated and formidable. For the new states, putting their topsy-turvy house in order proved even more difficult than regaining independence (note that Nepal also faced similar situation after the fall of Rana regime). The world was now devided into two conflicting camps: Socialist Camp and American Camp. They built on their colonial foundations and retained, almost unchanged, their political, economic and administrative heritage. They made gradual reform not revolution and maintained intimate relations with their old masters.

From 1950 onwards, America was the undisputed leader of the "free world" camp. The leader was determined to restrain, by hot or cold war, the expansion of radicalism, and to bolster client nations. The great leader started aid programs all around the world. Apart from military aid, material aid was given in the shape of loans, grants, capital and consumer goods. Technical aid was provided in the form of experts, advisors and 
foreign training. And ideological aid flowed in through the diss. emination of orthodox economic and sociological wisdom. In the dawn of the fifties, rulers of many penurious states hopefully regarded America as the good fairy and foreign aid as a magic wand.

During this decade, Americans sponsored two great rural programs. Community Development and Agricultural Extension. The former was newly fashioned by American Sociologists, while the latter was an old product of the American land grant colleges. G. D. promised political peace by including everyone in a harmonious community and putting an end to conflicts, it promised economic prosperity by inculcating the desire for development and by securing common participation. As a weapon to the cold war, C. D. offered the quietism of consensus as a superior alternative to turbulent radicalism.

C. D. relied mainly on a government village level worker $(V L W)$ as the agent of charge. In Nepal too, community development approach was imported from India under the name of Village Development Program in 1951; and first the VLWs and later the Junior Technical Assistants (JTA) were the agents of change. This change agent was advised to collaborate closely with local people/" natural" leader. Evidently VLW/JTA came to help everybody, not by fighting for the weak against the strong, but by uniting all of them, weak or strong. into a fraternal community. Surely all could join hands for the sake of development.

The VLW was a catalytic-agent who would unite villagers and help them find their felt and unfelt needs. He would teach them to form committees and councils for the completion of the projects. Now, and then a VLW would also encourage and stimulate the villagers by finding matching grants and technical assistance. A VLW was a multipurpose agent. He would combine the functions of a missionary, an organizer, a technician and a pation.C.D.aspired to coordinate the activities of other departments and follow an integrated approach its vision of development included the improvement of everything: social harmony, economic production, health and recreation. In the fifties C. D. became a world-wide movement. Nepal also did not remain untouched. But its decline was as sudden as its rise In 1964, USAID abolished its C D. division. In India too. after a decade of great faith and enormous investment in $C D$. as the best strategy for rural development, suddenly the emphasis shifted from C. D. to modernizing agriculture, building rural institutions, parchayats, cooperatives and land rerorm. Nepal followed the same path and since C. D. was quietly abandoned by both parents America and India, in Nepal too C. D. either was modified to various other kinds of program such as area development or integrated rural development program or it got limited to the project level in various externally funded development activities.

Traditional practice of self help had been in operation in Nepal from the historical past. Labour exchange is one of such mutually benefiting activities. Semi-formal organizations such as Municipality Cleaning office or the Chandra Weaving Extension Society date back to around early 1920 s. Similarly Development Board, Agriculture Council, welfare Society and National Planning Committees were established during the period 1935 to 1950 (K. C, 1990). Almost all of these Non-Governmental (NG) and Governmental $(\mathrm{G})$ organizations were basically meant for welfare activities.

Community Development Approach was introduced in Nepal only in 1951 under the name of village Development. As stated above, though welfare activities at the community level were not new to the Nepalese people, yet, externally introduced $C D$ programs lacked the integration of local wisdom, values and aspirations and thus were found unsuitable and could not sustain the community Supply of inputs such as improved seeds and chemical fertilizers in heavily subsidized rates or free distribution of medicines were some of the features of CD program. 
Assumption that farmers would continue to adopt those technologies after they knew and practised them came to be futile. Rather heavy subsidizatj in had a negative effect on farmers; it made them more dependent on GOS and/or NGOS which were responsible for it. Besides GOS, there were 13 Nepali NGOS at the nationTI level, 5 at the regional level and 154 at the local level. Similarly, there were 50 registered international NGOs of which 14 were directly related to CD activities in Nepal (K. C, 1990).

Program developed by the community members themselves which sought supplementary assistance from outside agencies are different from externally thought and brought projram which later sought participation from the community members. In Nepal, most of the CD type programs reflect outside agency's (GOs and NGOs) value judgements on deciding and implementing thc program. Mostly they tend to be different from people's needs and aspirations and hence lack people's participation at the desirable level. Thus CD type program appear to be of ad hoc in nature and after the figurative completion of the project, its impact usually become invisible; it is not sustained and the project rarely gets the status of an on-going people's program.

CD.

Khan (1977) mentions four crucial imperfection of

i. It promoted welfare actlvities more effectively than productive activities. Particularly, it seemed incapable of solving the national food crisis.

ii. $C D$ did not succeed significantly in forming harmonious communities It does not secure general participation. The poorer classes remained as they were, apathetic and sceptical.

iii. CD's reliance on its own agents and total collaboration with established leaders further confirmed the elitist and

64 paternalist bias, a colonial heritage, and inhibited the growth of true local initiative.

iv. $C D$ 's role as a generalist captain and coordinator was not acceptable to the specialist departments. Agricultural experts especially complained about the inadequacy of a multipurpose VLW as their agent.

\section{Concluding Remarks}

It is generally held that economic development occurs in a succession of capitalist stages and that today's underdeveloped countries are still in a stage, sometimes depicted as an original stage, of history through which the now developed countries passed long ago. It is also widely believed that the contemporary underdevelopment of a country can be understood as the product or reflection solely of its own economic, political, social and cultural characteristics or structure.

Yet historical research do not support these view points. Research demonstrates that contemporary underdevelopment is in large part the historical product of past and continuing economic and other relations between the satellite underdeveloped and the now developed metropolitan countries (Frank, Andre G., 1966).

When we examine this metropolis - satellite structure, we find that each of the satellites, (including underdeveloped Nepal), serves as an instrument to suck capital or economic surplus out of its own satellites and to channel part of this surplus to the world metropolis of which all are satellites.

The rural towns, which are themselves satellites of the urban metropolis - - and through the latter of the world metropolis - - are in turn rural centres around which their own local satellites orbit.

That present underdevelopment of Nepal can be explained from this conceptual framework and is the result of its 
century old participation in the process of world capitalist development. The rural-urban relationship makes a larger satellite - metropolis orbit to its giant neighbour which further becomes a satellite to the metropolis Europe.

The goal of development may never be achieved by importing sterile stereotypes from the metropolis which do not correspond to their economic reality and do not respond to their liberating political needs. A more historical, holistic, and structural approach may help the people of the underdeveloped countries to understand the causes and eliminate the reality of their development of underdevelopment and their underdevelopment of development.

Development is built on human aspirations and it is multifaceted: economic, social, political and intellectual. Since $C D$ has a democratic ideology, it deserves revitalized attention and promotion.

However, a theory which integrates micro-level ideals (such as $C D$ ) with the macro-level needs (human aspirations) have to be developed.

It is a challenge to the practitioners of rural development how a rural community, as a peripheral satellite, could be protected from its central metropolis and yet be brought into the mainstream of development.

At present, there appears to be more pronounced class consciousness in Nepal than before. Class conflict between 'haves' and 'have nots' is sharpening. Nepal is a country with predominently rural or rather peasant population with a low level of industrialization, a high level of unemployment rate, poverty, low level of education, and ill health. In countries of such social structure, the main social conflict arise between peasantry and landed aristocracy.
In such a situation, program of development, such as improved agricultural technologies, better transportation and communication, education and medical health and so on would rather sharpen social conflicts.

The majority of the peasants are too poor to benefit from such technologies. New opportunities created by such purely technical progress of development will be mostly utilized by the upper and middle strata. Since progress of development would further sharpen social conflicts, it indicates that such progress may lead to unanticipated results.

It has been observed that progress of development could be more effective if they are applied by new political power (Galeski, n.d.) which emerged during the process of change in the general socio-economic situation, the new power would be temporarily free of basic social conflicts and program of development could be more flexible in creating a new socioeconomic system and new social structure. Since Nepal is passing through similar situations at present, there is every reason we believe change which leads to prosperity.

\section{Referēences:}

Frank, Andre G. 1966 "The Development of Underdevelopmont", Monthly Review.

Galeski, B.

n. d. "Conflicts and Changes as an Aspect of Development", Paper presented during the author's stay in the U. S. under the United States Department of State Exchange Program.

Hillery, George A.n.d. "Definations of Community: Areas of Agreement". Handout distributed in the Course Soc. 978. MSU. 
Khan, Akhter H. 1977

K.C.. Krish B. 1990
Ten Decades of Rural DevelopmentLessons from India. East Lansing: MSU.

Community Development - The Nepalese Context. Kathmandu: Society for Community Development Professionals.

$\hbar$

\section{National Integration In Nepal}

- Dr. Ganesh Gurung*

- Dr. Bishnu Bhandari

\section{Concept and Definition:}

National integration is an emotional attachment to nation (Etzimi, 1965); a process as well as an end product (Angel, 1941); a condition achievable by a nation (Aberle and Fordon as quoted in Doshi, 1978, and 1989); a condition and process (Ghurye, 1968; and Cohon \& Middleton as quoted in Doshi, 1978). Ghurye emphasizes that it consists of two elements: political integration and social integration. All these above definitions suggest that integration is a drawing together of those elements into something more cohesive with the parts linked more closely together co-existence. It is through this process that people develop a deep sense of we-feeling and belongingness and thereby a feeling of national loyality. Through this process, it is possible to maintain a harmonious and lively relationship between the various structural components of

*Lecturer and Reader respectives at Tribhuvan University would like to thank their colleagues for their comments and suggestions. 